UDC $676.166 .6+676.24$

\author{
I.V. Trembus, N.V. Sokolovska, V.V. Halysh, J.V. Nosachova, T.A. Overchenko
}

\title{
LOW-TEMPERATURE METHOD FOR MANUFACTURING OF CELLULOSE FROM WHEAT STRAW
}

\author{
National Technical University of Ukraine «Igor Sikorsky Kyiv Polytechnic Institute», Kyiv, Ukraine
}

\begin{abstract}
It is necessary to reduce the negative impact of the pulp and paper industry on the environment and to expand the raw material base. This problem can be solved by the development of new environmentally friendly methods of the production of pulp and cellulose from wastes of agriculture to fabricate different types of cardboard and paper products. This work is devoted to the investigation of the effect of reagents consumption, catalysts application and duration of delignification in a medium of acetic and formic acids on the quality indices of straw cellulose. Pulp of high quality was obtained with the yield in the range of 51.7 to $63.1 \%$ and with the content of residual lignin of 5.2 to $12.9 \%$. The indices of selectivity of lignin removal during organosolv delignification of wheat straw stems were calculated. The positive influence of $\mathrm{Na}_{2} \mathrm{WO}_{4} \cdot 2 \mathrm{H}_{2} \mathrm{O}, \mathrm{MoWO}_{4} \cdot 2 \mathrm{H}_{2} \mathrm{O}$ and $\mathrm{TiO}_{2}$ on the delignification of non-wood material with the use of a mixture of organic acids was shown. The physical-mechanical indices of organosolv straw cellulose were determined; they are not inferior to kraft cellulose which indicates the possibility of the use of organosolv straw cellulose in the production of paper and cardboard.
\end{abstract}

Keywords: wheat straw, organic acids, delignification, cellulose, catalyst, quality indices.

DOI: $10.32434 / 0321-4095-2019-122-1-116-122$

\section{Introduction}

Taking into account long-term global economic growth and the fact that demand for cardboard and paper products in the world will grow by $1.1 \%$ by 2030, an increase in the volumes of pulp production is required. The main raw materials for the production of pulp and cellulose are softwoods and hardwoods. The search for new alternative sources of fiber for the needs of the pulp and paper industry is an urgent problem in countries where the stock of wood is limited [1,2]. Non-wood plant materials, in particular the stems of cereal crops, can be regarded as promising raw materials. The main advantage of such type of materials is their annual renewal and lower cost compared to wood [3].

The use of non-wood plant materials for preparing pulp and cellulose is associated with the development of modern delignification processes. It allows combining the benefits of traditional cooking with the requirements of reducing emissions of harmful substances into the environment. Sulfate and sulfite methods of cellulose fabrication, which are commonly used in the world practice of pulp and paper industry, are accompanied by the formation of toxic volatile sulfur-containing compounds (hydrogen sulfide and mercaptans). The contamination of water objects of the environment with lignin-containing products is also observed [4].

From an environmental point of view, preparation of pulp and cellulose from non-wood materials in medium of various organic solvents is considered as a promising solution. Delignification with organic solvents, organosolv pulping, significantly reduces environmental pollution. Solutions of aliphatic and aromatic alcohols, carboxylic and organic acids, ketones and ethers can be used as organic compounds for the delignification process [5]. These compounds are significantly different in their properties and the nature of interaction with the components of plant material.

Catalytic oxidation methods of non-woods with hydrogen peroxide in acidic medium are proposed as an alternative to traditional delignification methods [6]. Hydrogen peroxide is a soft oxidizer and considered as one of the most environmentally acceptable reagents for delignification processes. It reacts with organic acids with the formation of peracids which are characterized by high a

(C) I.V. Trembus, N.V. Sokolovska, V.V. Halysh, J.V. Nosachova, T.A. Overchenko, 2019 
delignification activity and can be generated during delignification process. The use of organic peracids at the concentration of $4-10 \%$ allows performing the delignification of plant material at atmospheric pressure, temperatures of up to $100^{\circ} \mathrm{C}$ and reducing the consumption of fresh water [7]. However, the application of hydrogen peroxide greatly increases the cost of obtained pulp and cellulose.

Widespread use of such acids as acetic and formic as a medium for delignification processes is connected with their high ability to dissolve lignin. The application of these organic acids provides high yield of pulp and cellulose due to the soft conditions of delignification and allows eliminating the use of chlorine compounds in the further process of cellulose bleaching [7]. Delignification with organic acids does not lead to the degradation of high molecular weight components of plant material. Such pulping involves the possibility to utilize hemicelluloses of plant materials and isolate reactive lignin which can be easily processed into valuable chemical products [8].

The application of inorganic acids and salts as catalytic additives during cooking leads to improvement of the quality of pulp [9]. However, inorganic acids can promote the corrosion activity and accelerate the hydrolysis of polysaccharides during pulping of wood and non-wood materials. Compounds of tungsten, molybdate and titan are regarded as the most effective catalysts of delignification. They react with hydrogen peroxide with the formation of an intermediate inorganic peroxocomplexes that transfer oxygen to an organic acid promoting the formation of peracids [10].

Technologies of oxidative organosolv delignification of plant material based on the application of peracids are sufficiently broadly covered in literature $[7,8,11]$, in contrast to the production of wheat straw pulp in acetic and formic acid media. Therefore, the purpose of the work was to develop technique for the production of straw pulp in a medium of organic acids with the application of catalysts which will be suitable for the fabrication of various types of cardboard and paper products. To achieve the goal, the following tasks were set: to investigate the effects of the concentration of the reagents, their ratio and duration of the process of wheat straw delignification in a medium of acetic and formic acids on the characteristics of straw cellulose; to study the influence of the application of compounds of tungsten, molybdate and titan as catalysts on strength indices of organosolv straw pulp; to select an appropriate catalyst and to determine its optimum consumption.

\section{Materials and methods}

Wheat straw (Triticum vulgare) was used for the production of cellulose. The chemical properties of straw were determined in accordance with the corresponding TAPPI standards [12] for various components, namely: T-222 for lignin, T-257 for substances extracted with hot water, T-212 for substances extracted with $1 \%$ solution $\mathrm{NaOH}$, T-204 for substances extracted with an alcoholbenzene solution, and T-211 for ash. The chemical composition of raw material was as follows: cellulose $45.6 \%$; lignin $17.1 \%$; solubility in hot water $10.6 \%$; solubility in $\mathrm{NaOH} 37.2 \%$; resins, fats and waxes $5.4 \%$; ash $6.9 \%$.

Wheat straw was delignified by a solution containing formic acid $(\mathrm{HCOOH})$ and acetic acid $\left(\mathrm{CH}_{3} \mathrm{COOH}\right)$ at a ratio of from 30:70 to $80: 20 \mathrm{vol} . \%$. Organic acids were used at the concentrations of 40 and $60 \%$, respectively. Delignification was carried out at a solid to liquid ratio of 10: 1 for 60 to $180 \mathrm{~min}$ at the temperature of $90 \pm 2^{\circ} \mathrm{C}$. In order to prevent the loss of the solution, the delignification process was performed in heat-resistant flasks connected with reverse refrigerators. Compounds of tungsten $\left(\mathrm{Na}_{2} \mathrm{WO}_{4} \cdot 2 \mathrm{H}_{2} \mathrm{O}\right)$, molybdenum $\left(\mathrm{MoWO}_{4} \cdot 2 \mathrm{H}_{2} \mathrm{O}\right)$ and titanium $\left(\mathrm{TiO}_{2}\right)$ with the consumption from 1 to $5 \%$ were used as catalysts. The obtained pulp was washed with water and then air-dried. The yield of pulp was determined gravimetrically and the content of the residual lignin was stated according to the standard techniques of TAPPI [12].

To determine the mechanical indices, the obtained straw pulp was milled to $60 \pm 2{ }^{\circ} \mathrm{SR}$, and paper sheets with a mass of $75 \pm 1 \mathrm{~g} / \mathrm{m}^{2}\left(1 \mathrm{~m}^{2}\right)$ were made. Mechanical parameters of cellulose were also determined according to the standard TAPPI methods [12].

\section{Results and discussion}

Effect of wheat straw delignification conditions on cellulose quality indices

In order to determine the effect of the concentration of organic acids on the properties of pulp, the delignification of wheat straw by a mixture of formic acid and acetic acid at the ratio of 50:50 vol.\% during 60-180 min was carried out. The characteristic of the prepared straw pulp are shown in Fig. 1.

As can be seen from Fig. 1, the yield of pulp decreases with an increase in the concentration of reagents and the process duration. This is due to the intensification of the lignin destruction process by acid splitting of $\alpha$-ether bonds of lignin with the formation of intermediate benzyl carbocationse (Fig. 2). It can be the reason for easier delignification 


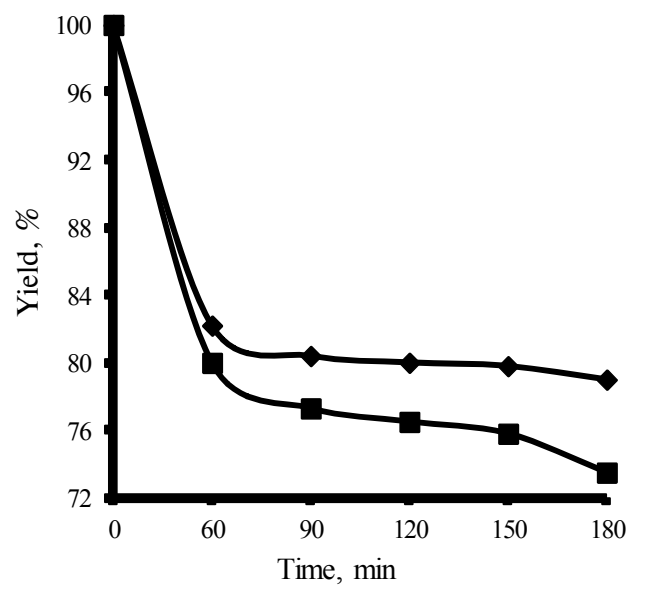

a

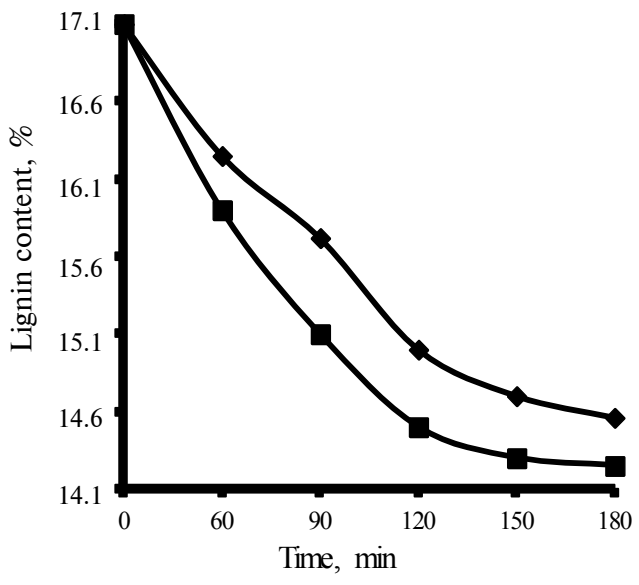

b

Fig. 1. Dependences of yield (a), and content of lignin (b) on the time of the delignification process in organic acids with the concentrations $40 \%(\bullet)$ and $60 \%$

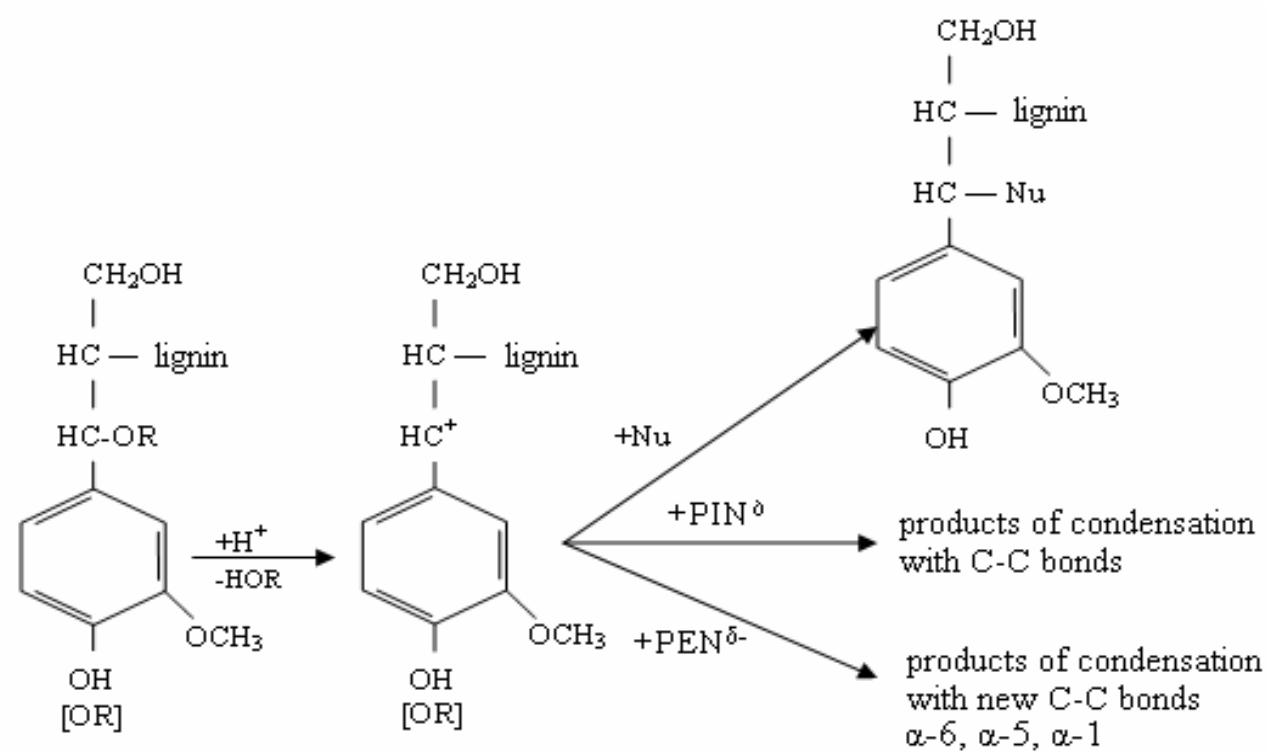

Fig. 2. Splitting of $\alpha$-etheric bonds of lignin during organosolv cooking of plant material in acid medium:

$\mathrm{Nu}$ - external nucleophile ( $\mathrm{HOH}, \mathrm{C}_{2} \mathrm{H}_{5} \mathrm{OH}, \mathrm{CH}_{3} \mathrm{OH}$, etc.); $\mathrm{PIN}^{--}-$internal nucleophile (phenyl propane unit of lignin); $\mathrm{PEN}^{\delta-}-$ external nucleophile of phenolic type (phenol, cresols, etc.)

of non-wood plant material in which the proportion of non-cyclic structures of $\alpha$-aryl ether, responsible for the destruction of lignin, is almost 2 times higher than that of lignin coniferous species. In this case, the organic solvent, as a weak nucleophile, blocks the active centers of lignin and prevents the process of its condensation.

It should be noted that the $\beta$-etheric bonds of lignin, especially the $\beta-\mathrm{O}-4$ bond (Fig. 3 ), are also subject to degradation during organosolv delignification in the acidic medium, which also leads to reducing the yield of straw pulp.

But, it should be also noted that it is possible to obtain only semi-cellulose with a yield of 73 to $82 \%$ under such conditions of organosolv delignification.

The content of residual lignin in the resulting pulps is in the range of $14-16.2 \%$. Delignification of wheat straw according to proposed scheme allows removing only $3 \%$ of lignin from plant material. Therefore, the organosolv delignification process of plant material is better to carry out during 150180 min with the concentration of organic acids which is not less than $60 \%$.

In order to intensify wheat straw delignification process and hence reduce the residual lignin content 


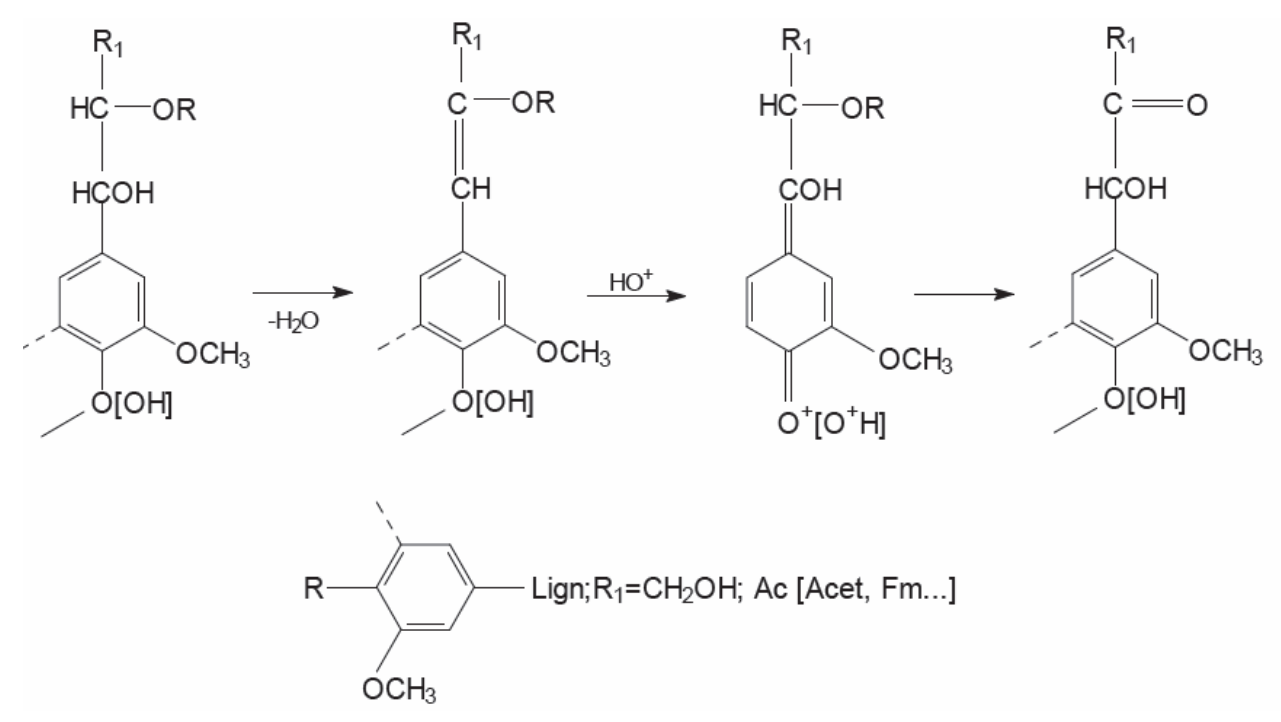

Fig. 3. The mechanism of $\beta-\mathrm{O}-4$ bond cleavage

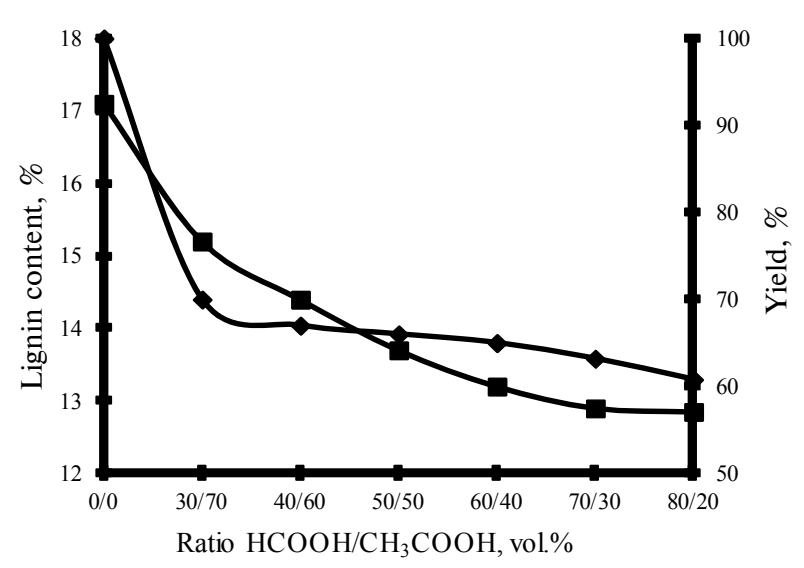

Fig. 4. Effect of the ratio of organic acids on the quality of straw pulp: $\bullet$ - yield; $\mathbf{\square}-$ lignin content

in pulp, the influence of various ratios of organic acids on their quality indices was investigated (Fig. 4). The non-wood material was delignified with organic acids with the concentration $60 \%$ during $180 \mathrm{~min}$.

The obtained results (Fig. 4) indicate that increasing the content of formic acid in an acid solution leads to a decrease in the yield of pulp and in the residual lignin content. Under such conditions, the processes of acidolysis and acid fragmentation of lignin, the cleavage of lignin-carbohydrate bonds and the destruction and dissolution of hemicelluloses are activated.

The solubility parameter is usually used to evaluate the solvent affectivity in relation to the polymers [10]. It was established that the maximum soluble capacity is observed for solvents with a solubility parameter of $22.5\left(\mathrm{~J} / \mathrm{cm}^{3}\right)^{0.5}[13]$. The values of this parameter for acetic and formic acids are 20.7 and $24.7\left(\mathrm{~J} / \mathrm{cm}^{3}\right)^{0.5}$, respectively. This can explain the acceleration of the delignification process of plant material with an increase in the content of $\mathrm{HCOOH}$ in a delignification solution.

It should be noted that the content of residual lignin in the obtained straw pulp decreases significantly at the ratio of $\mathrm{HCOOH}$ to $\mathrm{CH}_{3} \mathrm{COOH}$ of $80: 20$ vol.\%, while the pulp yield reduces appreciably. This is the evidence of the process of destruction of the carbohydrates of plant material. Therefore, the process of organosolv delignification of wheat straw should be carried out at a ratio $\mathrm{HCOOH}$ to $\mathrm{CH}_{3} \mathrm{COOH}$ of $70: 30$ vol.\%. The selectivity (SL), degree of delignification (DD), degree of carbohydrate removal (DCR) and optimality of process (OPT) [14] for this acids ratio were calculated and the results are given in Table 1. As can be seen, the optimal values of mentioned parameters of wheat straw delignification process were achieved for the ratio of $\mathrm{HCOOH}$ to $\mathrm{CH}_{3} \mathrm{COOH}$ of 70:30 vol.\%.

\section{Catalyst application}

In order to intensify the process of organosolv delignification of wheat straw under the specified optimal conditions (the ratio of $\mathrm{HCOOH}$ to $\mathrm{CH}_{3} \mathrm{COOH}$ of $70: 30 \mathrm{vol} . \%$, the temperature of $90^{\circ} \mathrm{C}$, the duration of $120 \mathrm{~min}$ ), the delignification was performed using the following catalysts: $\mathrm{Na}_{2} \mathrm{WO}_{4} \cdot 2 \mathrm{H}_{2} \mathrm{O}, \mathrm{MoWO}_{4} \cdot 2 \mathrm{H}_{2} \mathrm{O}$ and $\mathrm{TiO}_{2}$. The effects of catalysts on the quality indices of the obtained straw pulp are shown in Fig. 5.

The use of various catalysts during delignification accelerates the process of lignin dissolving and reduces the content of residual lignin 
Table 1

Indices of the selectivity of lignin dissolution during delignification of wheat straw by organic acids

\begin{tabular}{c|c|c|c|c}
\hline $\begin{array}{c}\text { Ratio of HCOOH to } \\
\mathrm{CH}_{3} \mathrm{COOH}, \text { vol. \% }\end{array}$ & $\begin{array}{c}\text { Degree of } \\
\text { delignification, DD, \% }\end{array}$ & Selectivity, SL, \% & $\begin{array}{c}\text { Degree of carbohydrates } \\
\text { removal, DCR, \% }\end{array}$ & $\begin{array}{c}\text { Optimality of } \\
\text { process, OPT, \% }\end{array}$ \\
\hline $30: 70$ & 37.8 & 74.8 & 28.4 & 28.3 \\
\hline $40: 60$ & 41.7 & 73.3 & 29.9 & 30.6 \\
\hline $50: 50$ & 44.6 & 72.7 & 30,3 & 32.4 \\
\hline $60: 40$ & 47.1 & 71.6 & 31.5 & 33.7 \\
\hline $70: 30$ & 52.3 & 69.1 & 33.9 & 36.1 \\
\hline $80: 20$ & 53.3 & 67.0 & 36.4 & 35.7 \\
\hline
\end{tabular}

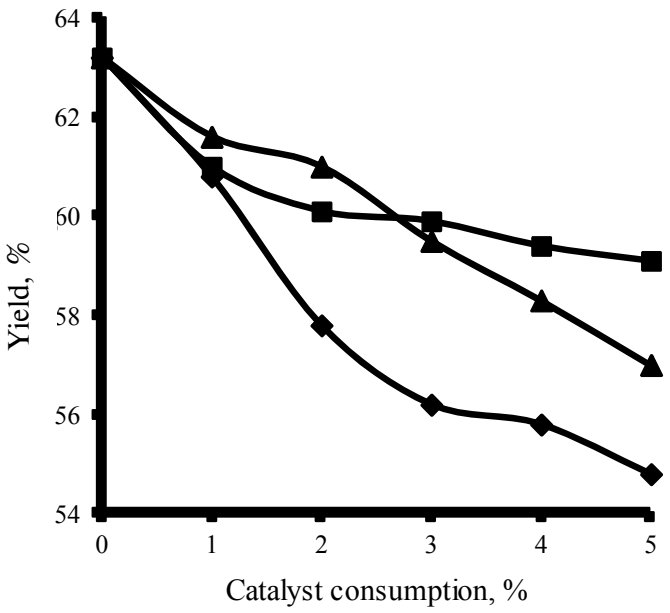

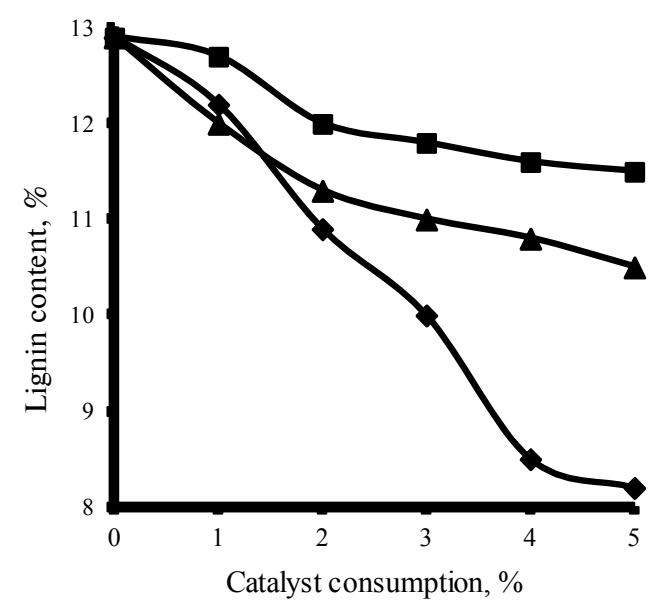

b

Fig. 5. Dependences of the pulp yield (a) and residual lignin content (b) on the catalyst consumption: $-\mathrm{Na}_{2} \mathrm{WO}_{4} \cdot 2 \mathrm{H}_{2} \mathrm{O}$;

$$
\text { - }-\mathrm{Na}_{2} \mathrm{MoO}_{4} \cdot 2 \mathrm{H}_{2} \mathrm{O} ; \boldsymbol{\Delta}-\mathrm{TiO}_{2}
$$

in the obtained pulp in the range of $0.7-4.7 \%$, the yield being decreased from 2.0 to $8.4 \%$. Sodium tungsten shows the highest selectivity in relation to lignin since the content of residual lignin in the pulp reduces by almost $5 \%$ compared to the non-catalytic delignification.

The maximum efficiency of sodium tungsten is achieved at its consumption of $4 \%$. In this case, the maximum decrease in the content of residual lignin in the obtained pulp with minimum pulp yield losses is observed (Fig. 5). A further increase in the catalyst consumption up to $5 \%$ is not economically feasible as there is no noticeable improvement in the quality of straw pulp.

In order to determine the effect of the catalyst on the physical and mechanical characteristics of straw pulp, the delignification of wheat straw was carried out under the optimum conditions with the application of sodium tungsten catalyst with the consumption of $4 \%$. The strength indices of the resulting organosolv pulp are shown in Table 2.

The analysis of the data presented in Table 2 shows that the application of a catalyst during
Table 2

Quality and strength indices of organosolv straw pulp

\begin{tabular}{|c|c|c|c|c|c|}
\hline \multirow{2}{*}{$\begin{array}{c}\text { Indices of } \\
\text { pulp }\end{array}$} & \multirow{2}{*}{ Catalyst } & \multicolumn{4}{|c|}{ Time, $\min$} \\
\hline & & 120 & 150 & 180 & 210 \\
\hline \multirow{2}{*}{$\begin{array}{l}\text { Pulp yield, } \\
\%\end{array}$} & absent & 63.1 & 60 & 55.7 & 55.3 \\
\hline & present & 55.8 & 54.1 & 53.3 & 51.7 \\
\hline \multirow{2}{*}{$\begin{array}{l}\text { Lignin } \\
\text { content, \% }\end{array}$} & absent & 12.9 & 12.5 & 10.2 & 9.03 \\
\hline & present & 8.5 & 7.4 & 6.0 & 5.2 \\
\hline \multirow{2}{*}{$\begin{array}{l}\text { Breaking } \\
\text { length, m }\end{array}$} & absent & 2400 & 2980 & 3760 & 4050 \\
\hline & present & 3030 & 3950 & 4480 & 4810 \\
\hline \multirow{2}{*}{$\begin{array}{l}\text { Tear index, } \\
\mathrm{mN}\end{array}$} & absent & 200 & 250 & 290 & 340 \\
\hline & present & 240 & 280 & 320 & 380 \\
\hline \multirow{2}{*}{$\begin{array}{l}\text { Burst } \\
\text { index, } \mathrm{kPa}\end{array}$} & absent & 195.5 & 236.5 & 286.2 & 347.2 \\
\hline & present & 214.6 & 254.7 & 315.9 & 369.9 \\
\hline
\end{tabular}

delignification improves the physical and mechanical properties of the obtained straw pulp. At the same time, an increase in the physical and mechanical characteristics of the obtained pulp with increasing duration of the process due to deeper delignification and preservation of hemicelluloses will contribute 
to the formation of additional hydrogen bonds between polysaccharides and improve the quality indices of pulp. The physical and mechanical characteristics of the resulting organosolv pulp fabricated from wheat straw are not inferior to kraft cellulose [14], which indicates the prospect of its use in the pulp and paper industry for the production of different types of paper and cardboard.

\section{Conclusions}

The influence of the main technological parameters of the delignification process on the quality indices of straw pulp was investigated. It was found out that increasing the concentration and content of formic acid reduces the yield of the pulp and the content of lignin by 13.1 and $4.6 \%$, respectively.

It was experimentally confirmed that the optimal parameters of delignification of wheat straw by a mixture of organic acids are as follows: the ratio of $\mathrm{HCOOH}$ to $\mathrm{CH}_{3} \mathrm{COOH}$ of 70:30 vol.\%, the acids concentration of $60 \%$, the temperature of $90^{\circ} \mathrm{C}$, the process duration of $120-210 \mathrm{~min}$.

It was shown that with increasing the content of $\mathrm{HCOOH}$ in solution, the selectivity of the process decreases, the degree of delignification and the degree of removal of carbohydrates increase.

It was found out that sodium tungsten shows the highest catalytic effect on the process of delignification. The delignification of wheat straw by $\mathrm{Na}_{2} \mathrm{WO}_{4} \cdot 2 \mathrm{H}_{2} \mathrm{O}$ with the consumption of $4 \%$ promotes a decrease in the lignin content in the pulp and the growth of its physical and mechanical characteristics.

\section{REFERENCES}

1. Pulp and paper-making potential of corn husk / Fagbemigun T.K., Fagbemi O.D., Otitoju O., et al. // Int. J. AgriScience. - 2014. - Vol.4. - No. 4. - P.209-213.

2. A review on pulp manufacture from non wood plant materials / Kamoga O., Lwako M., Byaruhanga J.K., et al. // Int. J. Chem. Eng. Appl. - 2013. - Vol.4. - No. 3. - P.144-148.

3. Safdari V., Sigarody M.R.N., Ahmed M. Identification of fibers of woody and non-woody plant. Species in pulp and papers // Pak. J. Bot. - 2011. - Vol.43. - No. 4. - P.2127-2133.

4. Processing of waste from pulp and paper plant / Oral J., Sikula J., Puchyr R., et al. // J. Cleaner Prod. - 2005. - Vol.13. - P.509-515.

5. Akgul M., Tozluoglu A. Alkaline - etanol pulping of cotton stalks // Sci. Res. Essays. - 2010. - Vol.5. - No. 10. P.1068-1074.

6. Trembus I.V., Trophimchuk Ju.S., Galysh V.V. Preparation of pulp from sunflower stalks using peroxy acids // Voprosy Khimii i Khimicheskoi Tekhnologii. - 2018. - No. 2. - P.122-127.

7. Delignification of wheat straw using a mixture of carboxylic acid and peroxoacids / Kham L., Le Bigot Y., Delmas M., Avignon G. // Ind. Crop. Prod. - 2005. - Vol.21. P.9-15.

8 Comparison of dilute mineral and organic acid pretreatment for enzymatic hydrolysis of wheat straw / Kootstra A.M.J., Beeftink H.H., Scott E.L., Sanders J.P.M. // Biochem. Eng. J. 2009. - Vol.46. - No. 2. - P.126-131.

9. Environmentally friendly catalytic production of cellulose by abies wood delignification in «acetic acid - hydrogen peroxide - water» media / Kuznetsova S.A., Danilov V.G., Kuznetsov B.N., et al. // Chem. Sustain. Develop. - 2003. - Vol.11. - P.141147.

10. Pen R.Z., Karetnikova N.V. Catalyzed delignification of wood with hydrogen peroxide and peracids (review) // Khimiya Rastitel'nogo Syr'ya. - 2005. - Vol.3. - P.61-73.

11. Barbash V., Poyda V., Deykun I. Peracetic acid pulp from annual plants // Cellulose Chem. Technol. - 2011. - Vol.45. - No. 9-10. - P.613-618.

12. Test methods. Atlanta: Tappi press. -2004.

13. Yoon S.H., Labosky P. Ethanol-kraft pulping and papermaking properties of aspen and spruse // Tappi J. - 1998. - Vol.81. - P.145-151.

14. Barbash V., Trembus I., Shevchenko V. Ammoniasulfite-ethanol pulp from wheat straw // Cellulose Chem. Technol. - 2014. - Vol.48. - No.3-4. - P.345-353.

Received 11.04.2018

\section{НИЗЬКОТЕМПЕРАТУРНИЙ МЕТОД ОДЕРЖАННЯ ЦЕЛЮЛОЗИ З ПШЕНИЧНОЇ СОЛОМИ}

І.В. Трембус, Н.В. Соколовська, В.В. Галиш, Ю.В. Носачова, T.A. Овериенко

Необхідною умовою подальшого розвитку целюлозно-паперової галузі є зниження негативного впливу підприємств на навколишнє середовище та розширення сировинної бази. Одним із шляхів вирішення иих проблем галузі є розробка нових екологічно безпечних способів одержання волокнистих напівфабрикатів із відходів сільського господарства для виробництва масових видів картонно-паперової продукції. Робота присвячена встановленню впливу витрат делігніфікуючих реагентів, каталізаторів і тривалості варіння в середовищі оцтової та мурашиної кислот на показники якості соломгяної целюлози. Одержано волокнисті напівфабрикати високої якості з виходом в інтервалі від 51.7 до $63.1 \%$ та вмістом залишкового лігніну від 5.2 до 12.9\%. Розраховано показники вибірковості вилучення лігніну органосольвентною делігніфікацією стебел пшеничної соломи. Показано позитивний вплив $\mathrm{Na}_{2} \mathrm{WO}_{4} \cdot 2 \mathrm{H}_{2} \mathrm{O}$, $\mathrm{MoWO}_{4} \cdot 2 \mathrm{H}_{2} \mathrm{O}$ та $\mathrm{TiO}_{2}$ на процеси варіння пшеничної соломи сумішшю органіних кислот. Визначено фізико-механічні показники органосольвентної соломтяної целюлози, які не поступаються kraft целюлозі та свідчать про можлливість ї̈ використання у виробництві паперу і картону.

Ключові слова: пшенична солома, органічні кислоти, делігніфікація, целюлоза, каталізатор, показники якості. 


\section{LOW-TEMPERATURE METHOD FOR MANUFACTURING OF CELLULOSE FROM WHEAT STRAW}

I.V. Trembus *, N.V. Sokolovska, V.V. Halysh, J.V. Nosachova, T.A. Overchenko

National Technical University of Ukraine «Igor Sikorsky Kyiv Polytechnic Institute», Kyiv, Ukraine

*e-mail: tivkpi@gmail.com

It is necessary to reduce the negative impact of the pulp and paper industry on the environment and to expand the raw material base. This problem can be solved by the development of new environmentally friendly methods of the production of pulp and cellulose from wastes of agriculture to fabricate different types of cardboard and paper products. This work is devoted to the investigation of the effect of reagents consumption, catalysts application and duration of delignification in a medium of acetic and formic acids on the quality indices of straw cellulose. Pulp of high quality was obtained with the yield in the range of 51.7 to $63.1 \%$ and with the content of residual lignin of 5.2 to $12.9 \%$. The indices of selectivity of lignin removal during organosolv delignification of wheat straw stems were calculated. The positive influence of $\mathrm{Na}_{2} \mathrm{WO}_{4} \cdot 2 \mathrm{H}_{2} \mathrm{O}, \mathrm{MoWO}_{4} \cdot 2 \mathrm{H}_{2} \mathrm{O}$ and $\mathrm{TiO}_{2}$ on the delignification of non-wood material with the use of a mixture of organic acids was shown. The physical-mechanical indices of organosolv straw cellulose were determined; they are not inferior to kraft cellulose which indicates the possibility of the use of organosolv straw cellulose in the production of paper and cardboard.

Keywords: wheat straw; organic acids; delignification; cellulose; catalyst; quality indices.

\section{REFERENCES}

1. Fagbemigun T.K., Fagbemi O.D., Otitoju O. Mgbachiuzor E., Igme C.C. Pulp and paper-making potential of corn husk. International Journal of AgriScience, 2014, vol. 4 , no. 4 , pp. 209-213.

2. Kamoga O.L.M., Byaruhanga J.K., Kirabira B.J. A review on pulp manufacture from non wood plant materials. International Journal of Chemical Engineering and Applications, 2013, vol. 4, no. 3 , pp. 144-148.

3. Safdari V., Sigarody M.R.N., Ahmed M. Identification of fibers of woody and non-woody plant. Species in pulp and papers. Pakistan Journal of Botany, 2011, vol. 43, no. 4, pp. 21272133.

4. Oral J., Sikula J., Puchyr R., Hajny Z., Stehlik P., Bebar L. Processing of waste from pulp and paper plant. Journal of Cleaner Production, 2005, vol. 13, pp. 509-515.
5. Akgul M., Tozluoglu A. Alkaline - ethanol pulping of cotton stalks. Scientific Research and Essays, 2010, vol. 5, no. 10, pp. 1068-1074.

6. Trembus I.V., Trophimchuk Ju.S., Galysh V.V. Preparation of pulp from sunflower stalks using peroxy acids. Voprosy Khimii i Khimicheskoi Tekhnologii, 2018, no. 2, pp. 122127.

7. Kham L., Le Bigot Y., Delmas M., Avignon G. Delignification of wheat straw using a mixture of carboxylic acid and peroxoacids. Industrial Crops and Products, 2005, vol. 21, pp. 9-15.

8. Kootstra A.M.J., Beeftink H.H., Scott E.L., Sanders J.P.M. Comparison of dilute mineral and organic acid pretreatment for enzymatic hydrolysis of wheat straw. Biochemical Engineering Journal, 2009, vol. 46, pp. 126-131.

9. Kuznetsova S.A., Danilov V.G., Kuznetsov B.N., Yatsenkova O.V., Alexandrova N.B., Shambasov V.K., Pavlenko N.I. Environmentally friendly catalytic production of cellulose by abies wood delignification in «acetic acid - hydrogen peroxide - water» media. Chemistry for Sustainable Development, 2003, vol. 11, pp. 141-147.

10. Pen R.Z., Karetnikova N.V. Catalyzed delignification of wood with hydrogen peroxide and peracids (review). Khimiya Rastitel'nogo Syr'ya, 2005, vol. 3, pp. 61-73.

11. Barbash V., Poyda V., Deykun I. Peracetic acid pulp from annual plants. Cellulose Chemistry and Technology, 2011, vol. 45, no. 9-10, pp. 613-618.

12. Test methods. Atlanta. Georgia. Tappi press. 2004.

13. Yoon S.H., Labosky P. Ethanol-kraft pulping and papermaking properties of aspen and spruse: Part II: Delignification kinetics, activation thermodynamics, and pulping productivity. Tappi Journal, 1998, vol. 81, no. 1, pp. 145-151.

14. Barbash V., Trembus I., Shevchenko V. Ammoniasulfite-ethanol pulp from wheat straw. Cellulose Chemistry and Technology, 2014, vol. 48, no. 3-4, pp. 345-353. 